\title{
Self Efficacy on Narrative Writing Ability of Primary School Student
}

\author{
Feby Inggriyani ${ }^{1}$, Nurul Fazriyah ${ }^{1}$ \\ ${ }^{1}$ Department of Primary School Education, Universitas Pasundan, \\ Jln. Tamansari No. 6-8 Kota Bandung, Jawa Barat 40154
}

\begin{abstract}
The purpose of this study is to obtain empirical data about the effect of self efficacy on the ability of writing narrative. The method used is survey with expostfacto technique. The study was conducted at Lengkong subdistrict Bandung city in fifth grade school year 2016/2017. Research sample at Pelita primary school and Karangpawulang primary school using purposive sampling technique was done to 283 students. Data collection techniques in this study is use questionnaire instrument for self efficacy using likert scale and data writing skills narrative done with essay test. Retrieval of data obtained through tests and analysis by simple linear regression with the help of SPSS version 17 software. The results of study showed that self efficacy has an effect on the ability to writing narrative class $\mathrm{V}$ student in nation primary school at Lengkong subdistrict Bandung city.
\end{abstract}

\section{Keyword: self efficacy; writing ability; writing narrative}

\section{INTRODUCTION}

Writing is one of the existing language competencies in every level of education, from preschool to college level, therefore writing skills get enough attention in the world of education. Writing or writing learning is the most difficult skill for students compared to other language skills [1]. Writing is an activity in thinking, digging up an idea into writing and in writing someone requires confidence and courage in displaying thoughts, feelings, ways of thinking and writing styles offered to others[2]. Thus, trust and courage in a person, can prevent him from the worry and anxiety when writing and when the results of his writings published. Therefore, in writing the belief is required to pour his ideas.

Based of observation and interview at the teacher in one of nation primary school in Lengkong subdistrict Bandung city showed that writing is less desirable activity, so students have difficulties in expressing their ideas and thoughts when writing narrative. The low level of student vocabulary is due to low reading interest, the lack of mastery of students' micro-skills such as the use of language marks, the 
use of word groups, the preparation of clauses and sentences with the correct structure until paragraph formulation.

One of successful in learning is self efficacy, which is one of the internal factors in a person that raises a strong conviction to be able to achieve certain results. Self efficacy is one of the most influential factors in doing something to one's motivation and achievement [3]. Individuals who have efficacy will motivate to carry out the given task and believe the results will be as expected. His beliefs make one try to get high learning results. Based on descriptions, the researcher felt the need to do a study that examines the internal factors that impact on the success of students in writing. Particularly in this study, researchers conducted a study the effect of self efficacy on writing narrative ability.

Writing ability is one of the four aspects of language skills. Through his writings, one can express his ideas and ideas in writing for publication. In addition, writing is one of the various uses of language and language skills reflected in a thinking ability. Writing can be said to be a combination of processes and products [4]. Where the process is when collecting ideas in writing, so as to create a text that can be read by the readers and is a product of the activities of the author. Writing skills are a language skill used to communicate indirectly [5]. The ability to write or compose can reflect the level of individual ability in composing and using ideas and communicating them in written form [6]. Thus, the ability to write not just write graphic symbols, form words, but sentences that have meaning and can communicate to the reader successfully $[7,8]$.

The term narrative comes from narrative = storytelling [9]. Narrative is a form of writing that seeks to create, narrate, coupling the actions of human actions in an event chronologically or in a unified time. This explains that in the narrative there is a series of stories that tell the story of human acts or deeds that are chronologically and systematically told, so the story is composed with a logical series of stories, the reader can see and experience the events themselves read. Narrative is a stries are not seen as simple reports of events of facts, nor are they seen as formed in the minds of individual writers apart from or unaffected by culture, material condition or context [10]. Heaton explains, in writing should pay attention to the five major components of language use, mechanical skills, content, language-style skills and skills consideration of the ability to write in an appropriate way in selecting and organizing relevant information [11]. Thus the 5 components become important in the learning and assessment of writing ability. Because these components are related to each other.

Based on the theories above, the ability to write a narrative in this research is the ability to pour ideas and organize the contents of the idea by writing an event or self experience that chronologically, resulting in a writing through sentence in accordance with the rules of writing correctly and right spelling by using a written test. The aspect of assessment narrative writing are, 1) content of the proposed idea includes, a) disclosure of ideas and b) conformity of the title with the contents of the text; 2) organization includes, a) plot, b) characterization, c) background and d) 
point of view, 3) the use of language that is structure; 4) Grammar, which is writing, spelling and punctuation. Writing is an activity, involved various internal factors that influence the writing activity. One of internal factor is self efficacy. Self-efficacy was first introduced by Albert Bandura. Self efficacy influences choice of activities, goals, and endeavors as well as persistence in class activities. Thus self-efficacy ultimately affects their learning and achievement [12]. Based on that, it can be understood that self-efficacy has a major contribution to one's motivation and achievement.

Feist and Gregory states that self efficacy is a form of belief in a person's ability to exercise control over the functioning of the person and the events in the environment [13]. In addition, Santrock explains that the cognitive view that is important to be developed by the child is self efficacy which is the belief of someone in mastering something and produce something good [14]. As for Luthans explains that self efficacy refers to "an individual's conviction" (or confidence) about his or her abilities to mobilize the motivations, cognitive resources and courses of action, execute a specific taks within a given context [14]. In essence, this definition provides the sense that self-efficacy refers to individual beliefs about its ability to drive the motivations, cognitive resources and ways of acting necessary to successfully perform the task in a particular context.

Ivancevish defines the concept of self efficacy consisting of three dimensions, namely: (a) Magnitude refers to the individual's belief in the ability to perform a task with a certain degree of difficulty successfully; (b) Strength refers to beliefs about the magnitude of power; (c) Generality, refers to a person's way of thinking by looking at a task in general, seeing tasks in different situations and conditions taking into account the capabilities possessed. Thus, from these three dimensions, it can be concluded that beliefs about self-ability by understanding the capabilities and situations of tasks that will occur, will consider the risk in completing the tasks that have been charged to him [15].

Based on the above theories, self efficacy in this research is the confidence of students for their ability to perform a task of writing narrative essay given by the teacher successfully. Self efficacy includes aspects of magnitude (level of difficulty of task), strength and generality (see in general about the extent of the field of behavior). Indicators for magnitude (task difficulty level) include: 1) confidence able to perform difficult tasks, 2) belief in the ability to strive harder to achieve success. Indicators for strength that includes 1) strong determination, 2) able to develop self potential. Indicators for generality 1) accept challenges and 2) accept new things.

\section{METHOD}

The approach of this research is quantitative. The method used is survey method with expost-facto technique. Population in this research is class V student at nation pimary school at Lengkong subdistrict Bandung city which took place in 
March - Mei 2017. Sampling technique using purposive sampling. This is done with several considerations, namely, the number of samples meet the criteria of research and adequate school facilities.

The sample of research taken at nation primary school Pelita and nation primary school Karangpawulang amounted to 283 students. Data collection techniques in this study 1) self efficacy using questionnaire instrument and converted by MSI, and 2) writing narrative abilities done using essay test. The data analisis technique in this study using simple linear regression with the help of SPSS version 17 software. For data normality using Kolmogorov-Smirnov and homogenenity using Levene test.

\section{RESULT AND DISCUSSION}

Based on table I, shows the relationship between self efficacy variables with writing narrative is 0.722. This shows that there is a relationship (positive correlation) between self efficacies with the ability to write narratives that fall into the high category. This is in accordance with the research which explains that there is a relationship between writing, self-belief and writing outcomes in college [17]. The results of the analysis yielded all studies of motivational conceptions of performance writing and self-efficacy that have the power to predict writing performance. In addition, Al-Mekhlafi studied the writing and self efficacy beliefs of a group of teachers [18]. He found a link between writing self efficacy and writing performance. Thus it can be concluded that the ability to write narrative is influenced by self efficacy. Here is a summary of the correlation model.

TABLE 1. SUMMARY OF CORRELATION MODEL

\begin{tabular}{|ccccc|}
\hline Model & $\mathbf{R}$ & R Square & $\begin{array}{c}\text { Adjusted R } \\
\text { Square }\end{array}$ & $\begin{array}{c}\text { Std. Error of the } \\
\text { Estimate }\end{array}$ \\
\hline 1 & $.722^{\mathrm{a}}$ & .521 & 0.520 & \\
\hline \multicolumn{3}{l}{ a. Predictors: (Constant), self efficacy } & & \\
\hline b. Dependent Variable: writing ability & & \\
\hline
\end{tabular}

Table I indicate that R square or correlation coefficient of 0.521 . That is, the coefficient of determination of $52.1 \%$. It can be said that the $52.1 \%$ variable of narrative writing ability can be explained by self efficacy variables. While the remaining $47.9 \%$ is explained or influenced by other factors. For example the physical condition of students, the ability to write early students, learning process activities, conditions of the circle and so forth. Thus, it can be concluded that self efficacy has an influence the ability to write narrative and high or low level self efficacy of a person is influenced by the other factors. This is accordance with the opinion of Schunk which explains, that one's self efficacy for a particular task at any 
given time may change due to preparation, physical condition (sickness, fatigue) and social environment (class condition in general) [19]. Thus it can be said that the different self efficacy is influenced by the ability demanded by different situations, the presence of others, especially rivals in the situation and the physiological and emotional state (weakness, anxiety, apathy and gloom). To determine the feasibility of the model then tested Anova. Summary of Anova test results can be seen in table II below.

Table II. Anova test summary

\begin{tabular}{|lcrrrr|}
\hline \multicolumn{1}{|c}{ Model } & $\begin{array}{c}\text { Sum of } \\
\text { Squares }\end{array}$ & Df & Mean Square & F & Sig. \\
\hline Regression & 3021.104 & 1 & 3021.104 & 305.979 & $0.000^{\mathrm{a}}$ \\
Residual & 2774.472 & 281 & 9.874 & & \\
Total & 5795.576 & 282 & & & \\
\hline a. Predictors: (Constant), Self Efficacy & & & & \\
\hline b. Dependent Variable & : Writing ability & & & & \\
\hline
\end{tabular}

Based on Table II, the Anova test obtained F count is 305.979 with a significance level of 0.000 . Because this probability is below 0.05 so that the regression model is appropriate to be used to explain the effect of self efficacy on students' narrative writing abilities. Regression model can be seen in table 3 below:

TABLE III. SUMMARY OF REGRESSION MODEL

\begin{tabular}{|c|c|c|c|c|c|c|c|c|}
\hline \multirow{3}{*}{ Model } & \multicolumn{7}{|c|}{ Coefficients $^{\mathrm{a}}$} & \\
\hline & \multicolumn{2}{|c|}{$\begin{array}{l}\text { Unstandardized } \\
\text { Coefficients }\end{array}$} & \multirow{2}{*}{$\begin{array}{c}\text { Standardized } \\
\text { Coefficients } \\
\text { Beta }\end{array}$} & \multirow{2}{*}{ t } & \multirow{2}{*}{ Sig. } & \multicolumn{3}{|c|}{ Correlations } \\
\hline & B & $\begin{array}{l}\text { Std. } \\
\text { Error }\end{array}$ & & & & $\begin{array}{l}\text { Zero- } \\
\text { order }\end{array}$ & Partial & Part \\
\hline (Constant) & 37.461 & 2.708 & & 13.831 & 0.000 & & & \\
\hline Efikasi_Diri & 0.584 & 0.033 & 0.722 & 17.492 & 0.000 & 0.722 & 0.722 & 0.722 \\
\hline
\end{tabular}

The regression model illustrates that the regression equation $\mathrm{Y}=37.461+$ $(0,584 X)$. The constant of 37.461 states that if there is no influence of the self efficacy variable then the ability to write a narrative of 37.461. The regression coefficient of 0,584 states that any increase in the value of self efficacy will increase the ability to write a narrative student. Thus, there is an influence between self efficacy on the writing narrative ability class $\mathrm{V}$ student nation primary school at Lengkong subdistrict Bandung city. In addition, it can be seen that the test results of 
regression equation with a significance value of 0.000 . This value is under the significance of 0.05 , thus the coefficient or regression model is significant or it can be said that self efficacy significantly affects the ability to write student narrative. There is influence between self efficacy by writing narrative because of self efficacy is one's internal factor in performing duty. This is in line with Dehghani's study which explains that self-efficacy as a motivating factor mainly influences critical thinking and lack of adequate motivation is an obstacle to the development of critical thinking [20]. Then the internal factors that involved can be said to be involved the cognitive process in writing narrative. Narrative writing involves a cognitive dimension that requires the author to connect various characters, ideas, facts and more and not an easy cognitive process [21]. So if students have poor self efficacy then this cognitive process is not well conditioned.

Lunenburg explains that self-efficacy has powerful effects on learning, motivation, and performance, because people try to learn and perform only those tasks that they believe they will be able to perform successfully[22]. Therefore, self efficacy is one of the decisive factors in determining the level of success of learning, especially in terms of writing narrative. Because it affects indirect feelings but also affects the class of other determinators either to train self-examination with personal challenges through goal setting. Therefore, self efficacy is very important to be owned by students in performing a particular task, so that the results have a positive impact. Cervone explains that person who is self efficacy higher than other tends to choose work on difficult tasks, persist in trying, staying calm and not anxious when facing tasks and managing thoughts in an analytical pattern [23]. Conversely, who have low efficacy when facing task tend to fail, easily give up when faced with difficult situations, tend to be anxious in performing tasks, often disturbed and fail to think calmly and analytically. Thus, the high and low self-efficacy of a person will have an effect on the performance of a person to do the task given and also affect the results to be achieved from a task he does.

\section{CONCLUSION AND IMPLICATION}

Based on the results of statistical analysis conducted, the findings of research is self-efficacy affect the ability to writing narrative class $\mathrm{V}$ student in nation primary school Lengkong subdistrict Bandung city. Thus, more high student self efficacy will be higher the ability to write student narratives. In addition, the help provided by the teacher during the sessions time and the exchanges that took place between the teacher and the students as well as among the students themselves were influential in improving students' writing. Furthermore, the classroom environment as a whole was of a crucial importance in improving the students' writings.

The success of the achievement of learning goals depends on the ability of teachers in choosing learning methods tailored to student self-efficacy factors. Selfefficacy is a key factor of the source of action that affects how students act with how 
much effort they are doing and how long they persist in facing obstacles and failures. Therefore, with regard to self efficacy, the teacher must recognize the characteristics of students tailored to the provision of effective and efficient learning methods so that the results of learning in accordance with the expected.

The implications for improving students' self efficacy in writing learning with teachers create contextual and fun learning. Teachers should be able to ensure that students can write based on their experiences with their confidence in their ability to improve what they want to achieve. Because with confidence in his ability will generate motivation in achieving success. For example, generate student confidence by using mind mapping learning method in writing. Thus, the left hemisphere is more often forced to think balanced with emphasis on the right hemisphere through the development of imagination, images and colors in an exciting sequence and will make the child more creative in grouping ideas.

Generate self-efficacy in students requires a trust that must be owned by students about the desire to succeed, therefore we must do is as follows: 1) Build a child's self-perception of the subject at school, 2) Strengthen student's academic self concept, 3) Building students' self-efficacy by using social modeling.

Thus, it is necessary effort to be done by teacher to increase self-efficacy of student in learning specially in writing. Besides creating a student-centered, comfortable learning atmosphere is one of the external factors teachers can do in the classroom.

\section{ACKNOWLEDGMENTS}

This work was supported by Ministry Research and Technology of Higher Education Indonesia, Beginner Lecturer Researcher Program, Project Research and Submission 2016-2017.

\section{REFERENCES}

[1] Sunarti, dan Subana. 2009. Strategi Belajar Mengajar Bahasa Indonesia. Bandung: Pustaka Setia. p.231.

[2] Yunus dkk. 2013. Keterampilan Menulis. Tangerang Selatan: Universitas Terbuka. p.1.3.

[3] Schunk, Dale H. 2012.Learning Theories an Educational Perspective. Yogyakarta: Pustaka Pelajar. p.205.

[4] Zainurrahman.2011. Menulis Dari Teori Hingga Praktik Penawar Racun Plagiarisme. Bandung: Alfabeta. p.8.

[5] Tarigan, Henry Guntur. 2008. Menulis Sebagai Suatu Keterampilan Berbahasa. Bandung: Angkasa Bandung. p.3.

[6] Jamaris, Martini. 2009. Kesulitan Belajar Perspektif, Assessmen dan Penanggulangannya. Jakarta: Yayasan Penamas Murni. p.219.

[7] Condon, William, Kelly Diane Riley. 2004. "Assessing And Teaching What We Value: The Relationship Between College-Level Writing And Critical Thinking Abilities,” Assessing Writing. 9(1):69. 
[8] Djiwandono, Soenardi. 2011. Tes Bahasa Pegangan bagi Pengajar Bahasa. Malang: Indeks. p.122.

[9] Finoza, Lamudin. 2009. Komposisi Bahasa Indonesia untuk Mahasiswa Nonjurusan Bahasa. Jakarta: Diksi Insan Mulia. p.244.

[10] McKinney, Jackie Grursch. 2013. Peripheral Visions for Writing Centers. University Press of Colorado. p.6.

[11] Salem, A.A. 2013. The Effect of Using Writer's Workshop Approach on Developing Basic Writing Skills (Mechanics of Writing) of Prospective Teachers of English in Egypt. English Language Teaching. 6(7):33.

[12] Ormrod, Jeanne Ellis. 2009. Psikologi Pendidikan: Membantu Siswa Tumbuh dan Berkembang (Edisi Keenam), terj. Amitya Kumara. Jakarta: Erlangga. p.21.

[13]Feist, Jess dan Gregory J. 2011. Feist. Teori Kepribadian, terj. Smita Prathita. Jakarta: Salemba Humanika. p.212.

[14] Santrock, Jhon W. 2011. Masa Perkembangan Anak Children Buku 2 Edisi 11. Jakarta: Salemba Humanika. p.225.

[15] Luthans, Fred. 2008. Organization Behavior, $11^{\text {th }}$ edition. Buston: Mcgraw-Hill. p.202.

[16] Ivancevish, John M. Robert Konopaske and Michael T. Matteson. 2008. Organizational Behavior and Management. USA: McGraw Hill. p.78.

[17] Hashemnejad, Felor, Zoghi, Masoud dan Amini, Davoud. 2014. "The Relationship between Self-efficacy and Writing Performance across Genders,” Theory and Practice in Language Studies. 4(5):1049.

[18] Al-Mekhlafi, Mohammad Abdu. 2014. "The Relationship between Writing Self-efficacy Beliefs and Final Examination Scores in a Writing Course Among a Group of Arab EFL Trainee-teachers, “International Journal for Research in Education (IJRE). 29:19.

[19] Santrock, Jhon W. 2008. Educational Psychology Third Edition (New York: McGraw-Hill Companies. p.462.

[20] Dehghani, Marzieh et.cl. 2011. Relationship between Students' Critical Thinking and Selfefficacy, Procedia Social and Behavioral Sciences. 3rd World Conference on Educational Sciences, Istanbul, Turkey.

[21] Soares, S.R, Soares, Aparecido JC., Cárnio, Maria Silvia. 2010. Written Narrative Practices In Elementary School Students. Pró-Fono Revista de Atualização Científica. out-dez;22(4), p.380.

[22] Lunenburg, Fred C. 2011. Self-Efficacy in the Workplace Implications for Motivation and Performance. International Journal Of Management, Business, And Administration, 14(1):12.

[23] Cervone, Daniel dan Lawrence A. Pervin. 2012. Kepribadian Teori dan Kepribadian, Personality: Theory and Research. Jakarta: Salemba Humanika. p.257.sss 